\title{
Observations of a Desmodesmus (Chodat) S.S. Ann, Friedl \& E. Hegewald (Sphaeropleales, Chlorophyta) and two Didymocystis Korshikov (Chlorellales, Chlorophyta) in Lake Tanganyika
}

\author{
Christine Cocquyt ${ }^{1 *}$, Laetitia Caljon ${ }^{2}, N^{\prime}$ 'sibula Mulimbwa ${ }^{3}$, Pierre-Denis Plisnier ${ }^{4}$ \\ 1 Research Department, Meise Botanic Garden, Meise, Belgium • christine.cocquyt@botanicgardenmeise.be \\ 2 Independent researcher, Geel, Belgium • caljon_laetitia@hotmail.com \\ 3 Centre de Recherche en Hydrobiologie - CRH-Uvira, Sud Kivu, Democratic Republic of the Congo • mulimbwa49@gmail.com \\ 4 Institut de Physique, Chemical Oceanography Unit, University of Liège, Liège, Belgium • pplisnier@gmail.com \\ * Corresponding author
}

\begin{abstract}
The occurrence of three species belonging to the small coenobia forming green algae Desmodesmus and Didymocystis is reported from the northernmost part of Lake Tanganyika, East Africa. During a monitoring between September 2011 and October 2013 the highest number of cells of Desmodesmus bicellularis and Didymocystis comasii were observed in August and September, at the end of the dry season. On the other hand, the third taxon, Didymocystis cf. inermis, was only sporadically observed between September 2011 and March 2012. According to existing databases, it should be the first records from Africa of these three species. However, D. bicellularis (as Didymocystis bicellularis) was already reported in 2003 in phytoplankton samples of the pelagic zone from more southern located places in Lake Tanganyika.
\end{abstract}

\section{Keywords}

Desmodesmus bicellularis, Didymocysts bicellularis, Didymocysts comasii, Didymocystis inermis, East African Great Lakes, phytoplankton, seasonality

Academic editor: Thaís Garcia da Silva | Received 11 February 2021 | Accepted 4 March 2021 | Published 1 April 2021

Citation: Cocquyt C, Caljon L, Mulimbwa N, Plisnier P-D (2021) Observations of a Desmodesmus (Chodat) S.S. Ann, Friedl \& E. Hegewald (Sphaeropleales, Chlorophyta) and two Didymocystis Korshikov (Chlorellales, Chlorophyta) in Lake Tanganyika. Check List 17 (2): $583-594$. https://doi.org/10.15560/17.2.583

\section{Introduction}

Didymocystis Korshikov sensu lato, a genus which was previously included in the Chlorococcales (Chlorophyta) (Komárek and Fott 1983) but now within the Chlorellales (Trebouxiophyceae, Chlorophyta) (Hegewald and Deason 1989), is only represented by a few species which are mainly known from temperate region (12 species according to Guiry in Guiry and Guiry 2020). Two species of this genus, Didymocystis fina Komárek (Komárek 1975) and Didymocystis comasii Komárek (Komárek 1983), have been described from tropical areas (Cuba). The latter taxon has also been reported from the Netherlands (Veen et al. 2015 in Guiry and Guiry 2020). Recently the genus Pseudodidymocystis E. Hegewald \& Deason was separated from Didymocystis based on cell wall structure and composition (Hegewald and Deason 1989). Four species have been transferred to this genus: Pseudodidymocystis 
planctonica (Koršhikov) E. Hegewald \& Deason, $P$. fina (Komárek) E. Hegewald \& Deason, P. inconspicua (Korshikov) Hindák, and $P$. lineata (Korshikov) Hindák (Hegewald and Deason 1989; Hindák 1990).

On the other hand, Didymocystis bicellularis (Chodat) Komárek was transferred to Desmodesmus (Chodat) S.S. Ann, Friedl \& E. Hegewald based on phylogenetic relationships (An et al. 1999). Within the Chlorophyta, the genus Desmodesmus is classified in the Sphaeropleales, Chlorophyceae.

During the phytoplankton study of samples taken weekly in a coastal and a pelagic site in the northernmost part of Lake Tanganyika near Uvira, Democratic Republic of the Congo (D.R. Congo), two taxa belonging to the genus Didymocystis and one to Desmodesmus were observed. These taxa have never been reported earlier for this tropical African lake (Cocquyt et al. 1993), probably due to their small dimensions of less than $10 \mu \mathrm{m}$ in length. No molecular data are available for the materials considered in this paper, as the studied samples were part of a monitoring project not including genetic analyses. Phytoplankton was collected in the frame of the CHOLTIC project (Cholera outbreaks at Lake Tanganyika induced by Climate Change?) (Plisnier et al. 2015) in addition to physico-chemistry and bacteriological data to understand the environmental ecology of copepods in Lake Tanganyika. Copepods have been identified in oceans as potential reservoirs of Vibrio cholerae bacteria (Colwell 1996). Thus, the aim of this project was to correlate physical, chemical, and biological data from Lake Tanganyika in relation with cholera outbreaks in order to improve an eco-hydrological model to understand triggering conditions of cholera outbreaks in the region. Phytoplankton blooms in the northern part of the lake have shown statistically significant correlation with cholera epidemics (Plisnier et al. 2015), although the precise environmental reservoir has not yet been identified. As an additional outcome of the project, new information collected on the phytoplankton species allowed to improve the knowledge of the phytoplankton community and its dynamics in Lake Tanganyika.

Temporal distribution and abundances of the three taxa in the surface water of Lake Tanganyika are given and discussed based on a three-year monitoring near Uvira (D.R. Congo) in the 2010s.

A

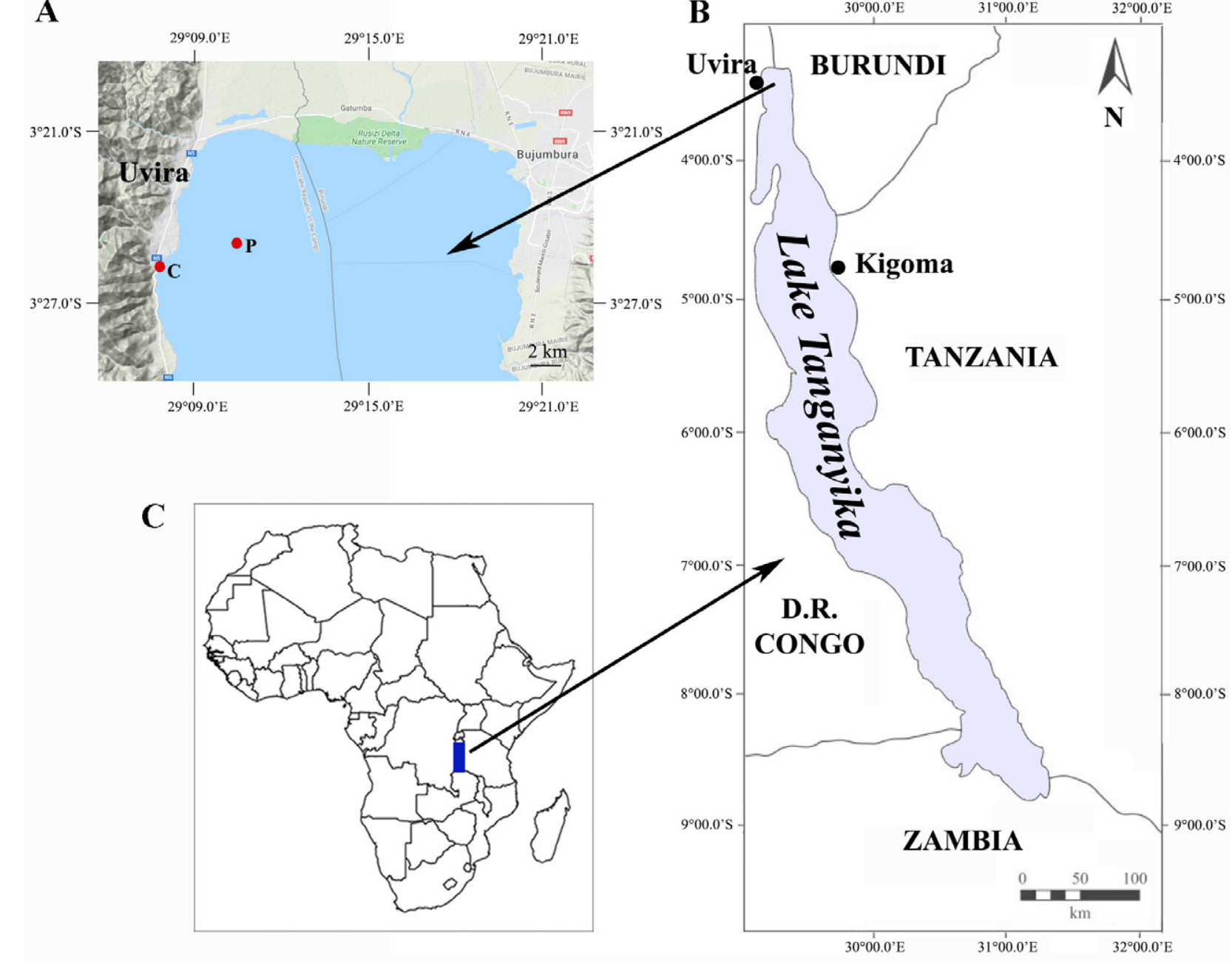

B

B $30^{\circ} 00.0^{\circ} \mathrm{E}$ $31^{\circ} 00.0^{\prime} \mathrm{E}$ $32^{\circ} 00.0^{\prime} \mathrm{E}$

Figure 1. Map with the location of the sampling points in Lake Tanganyika near Uvira (D.R. Congo). A. Detail of the northernmost part of the lake with indication of the pelagic (P) and the coastal (C) sampling point. B. Map of Lake Tanganyika with the location of Uvira (D.R. Congo) in the north of the lake. C. Map of Africa with the location of Lake Tanganyika (blue area). 


\section{Methods}

Phytoplankton samples were taken in the northernmost part of Lake Tanganyika near Uvira (DR Congo) in the frame of the CHOLTIC project (Plisnier et al. 2015). Sampling was done at a weekly base between 26 August 2011 and 15 October 2013 in a coastal $\left(03^{\circ} 25.648^{\prime} \mathrm{S}, 029^{\circ}\right.$ $\left.07.969^{\prime} \mathrm{E}\right)$ and a pelagic site $\left(03^{\circ} 24.945^{\prime} \mathrm{S}, 029^{\circ} 10.635^{\prime} \mathrm{E}\right)$ located about $3 \mathrm{~km}$ from the coast (Fig. 1). The weekly average water temperature for the water column (from $0 \mathrm{~m}$ to $100 \mathrm{~m}$ depth) was $26.0^{\circ} \mathrm{C}$ (minimum $25{ }^{\circ} \mathrm{C}$ and maximum $27.2{ }^{\circ} \mathrm{C}$ ). The thermic stratification was always observed, although the mixing zone varied between 20 and $100 \mathrm{~m}$ in depth with an average of 52 $\mathrm{m}$. Average water transparency at Uvira was $13.1 \mathrm{~m}$ and fluctuated between $9 \mathrm{~m}$ and $18.7 \mathrm{~m}$ during the three years of monitoring.

Two types of phytoplankton samplings were executed: a quantitative sampling by filling a $100 \mathrm{ml}$ bottle with lake water, and a semi-quantitative sampling with a phytoplankton net (mesh size of $10 \mu \mathrm{m}$ ). At the coastal site, a horizontal haul was taken for about $30 \mathrm{~m}$, just below the water surface; at the pelagic site. a vertical haul was taken in the upper $50 \mathrm{~m}$ in the water column. Quantitative samples were fixed in situ with an alkaline Lugol's solution and formalin, and net samples with formalin. Samples were kept cool and in the dark upon to transport and analysis in Belgium at the Meise Botanic Garden. Analyses followed the Utermöhl method (Utermöhl 1958) using sedimentation chambers of $10 \mathrm{ml}$, after concentration of the $100 \mathrm{ml}$ quantitative samples, and an Olympus CKX 41 inverted microscope equipped with an Olympus UC30 digital camera and an oil immersion objective of 100×. Biovolumes were calculated according to Hillebrand et al. (1999) from mean cell dimensions.

Samples are housed in the herbarium of the Meise Botanic Garden (BR) and were given a CCA (Christine Cocquyt Algae) collection number (Appendix Table A1).

\section{Results}

During the three years phytoplankton monitoring in the northernmost part of Lake Tanganyika near Uvira (D.R. Congo), three small coccoid green algae were observed. Komárek and Fott (1983) placed these three species within the genus Didymocystis. However, based on phylogenetic relationship one of these species was transferred to the genus Desmodesmus (Chodat) S.S. An, Friedl \& E. Hegewald (An et al. 1999). A short morphologic description of these three taxa as observed in Lake Tanganyika is given below.

Order Sphaeropleales

Family Scenedesmaceae

\section{Desmodesmus bicellularis (Chodat) S.S.An, Friedl \& E.Hegewald (1999)}

Figure 2A
Basionym: Scenedesmus bicellularis Chodat (1926).

Synonym: Didymocystis bicellularis (Chodat) Komárek (1973)

New records. D.R. CONGO • Sud-Kivu, Uvira, Lake Tanganyika; $03^{\circ} 25.648^{\prime} \mathrm{S}, 029^{\circ} 07.969^{\prime} \mathrm{E}$; $775 \mathrm{~m}$ a.s.l.; surface water; CHOLTIC expedition members leg.; CCA numbers in BR: 26 Aug. 2011; CCA 1602; 7 Sept. 2011; CCA 1618; 13 Sept. 2011; CCA 1626; 20 Sept. 2011; CCA 1634; 27 Sept. 2011; CCA 1642; 4 Oct. 2011; CCA 1650; 12 Oct. 2011; CCA 1658; 18 Oct. 2011; CCA 1666; 1 Nov. 2011; CCA 1682; 15 Nov. 2011; CCA 1698; 22 Nov. 2011; CCA 1706; 29 Nov. 2011; CCA 1714; 6 Dec. 2011; CCA 1722; 13 Dec. 2011; CCA 1730; 20 Dec. 2011; CCA 1738; 27 Dec. 2011; CCA 1746; 3 Jan. 2012; CCA 1754; 17 Jan. 2012; CCA 1770; 24 Jan. 2012; CCA 1778; 1 Feb. 2012; 1786; 7 Feb. 2012; CCA 1794; 14 Feb. 2012; CCA 1802; 21 Feb. 2012; CCA 2165; 28 Feb. 2018; CCA 2171; 6 Mar. 2012; CCA 2177; 20 Mar. 2012; CCA 2189; 27 Mar. 2012; CCA 2195; 3 Apr. 2012; CCA 2201; 24 Apr. 2012; CCA 2219; 3 May 2012; CCA 2225; 8 May 2012; CCA 2231; 29 May 2012; CCA 2249; 5 Jun. 2012; CCA 2256; 19 Jun. 2012; CCA 2268; 26 Jun. 2012; CCA 2274; 3 Jul. 2012; CCA 2280; 10 Jul. 2012; CCA 2286; 17 Jul. 2012; CCA 2292; 24 Jul. 2012; CCA 2299; 31 Jul. 2012; CCA 2305; 7 Aug. 2012; CCA 2311; 14 Aug. 2012; CCA 2317; 21 Aug. 2012; CCA 2323; 28 Aug. 2012; CCA 2329; 4 Sept. 2012; CCA 2335; 11 Sept. 2012; CCA 2341; 18 Sept. 2012; CCA 2348; 28 Sept. 2012; CCA 2354; 2 Oct. 2012; CCA 2360; 9 Oct. 2012; CCA 2366; 16 Oct. 2012; CCA 2372; 24 Oct. 2012; CCA 2378; 30 Oct. 2012; CCA 2384; 6 Nov. 2012; CCA 2390; 13 Nov. 2012; CCA 2396; 20 Nov. 2012; CCA 2402; 27 Nov. 2012; CCA 2408; 4 Dec. 2012; CCA 2414; 11 Dec. 2012; CCA 2420; 18 Dec. 2012; CCA 2427; 24 Dec. 2012; CCA 2433; 2 Jan. 2013; CCA 2439; 8 Jan. 2013; CCA 2445; 15 Jan. 2013; CCA 2451; 29 Jan 2013; CCA 2463; 5 Feb. 2013; CCA 2469; 12 Feb. 2013; CCA 2475; 19 Feb. 2013; CCA 2481; 26 Feb. 2013; CCA 2487; 6 Mar. 2013; CCA 2844; 19 Mar. 2013; CCA 2858; 26 Mar. 2013; CCA 2865; 2 Apr. 2013; CCA 2872; 9 Apr. 2013; CCA 2879; 16 Apr. 2013; CCA 2886; 23 Apr. 2013; CCA 2893; 7 May 2013; CCA 2907; 14 May 2013; CCA 2914; 24 May 2013; CCA 2921; 28 May 2013; CCA 2928; 4 Jun. 2013; CCA 2935; 11 Jun. 2013; CCA 2943; 18 Jun. 2013; CCA 2950; 2 Jul. 2013; CCA 2964; 9 Jul. 2013; CCA 2971; 23 Jul. 2013; CCA 2985; 29 Jul. 2013; CCA 2992; 6 Aug. 2013; CCA 2999; 13 Aug. 2013; CCA 3006; 20 Aug. 2013; CCA 3013; 27 Aug. 2013; CCA 3020; 3 Sept. 2013; CCA 3027; 17 Sept. 2013; CCA 3041; 24 Sept. 2013; CCA 3048; 1 Oct. 2013; CCA 3055; 8 Oct. 2013; CCA 3062; 15 Oct. 2013; CCA 3069 • Sud-Kivu, Uvira, Lake Tanganyika; $03^{\circ} 24.945^{\prime} \mathrm{S}, 029^{\circ} 10.635^{\prime} \mathrm{E} ; 775$ $\mathrm{m}$ a.s.l.; surface water; CHOLTIC expedition members leg.; CCA numbers in BR: 26 Aug. 2011; CCA 1604; 7 Sept. 2011; CCA 1620; 13 Sept. 2011; CCA 1628; 20 Sept. 2011; CCA 1636; 27 Sept. 2011; CCA 1644; 4 Oct. 2011; CCA 1652; 12 Oct. 2011; CCA 1660; 18 Oct. 2011; CCA 1668; 25 Oct. 2011; CCA 1676; 1 Nov. 2011; CCA 1684; 15 Nov. 2011; CCA 1700; 22 Nov. 2011; CCA 1708; 29 

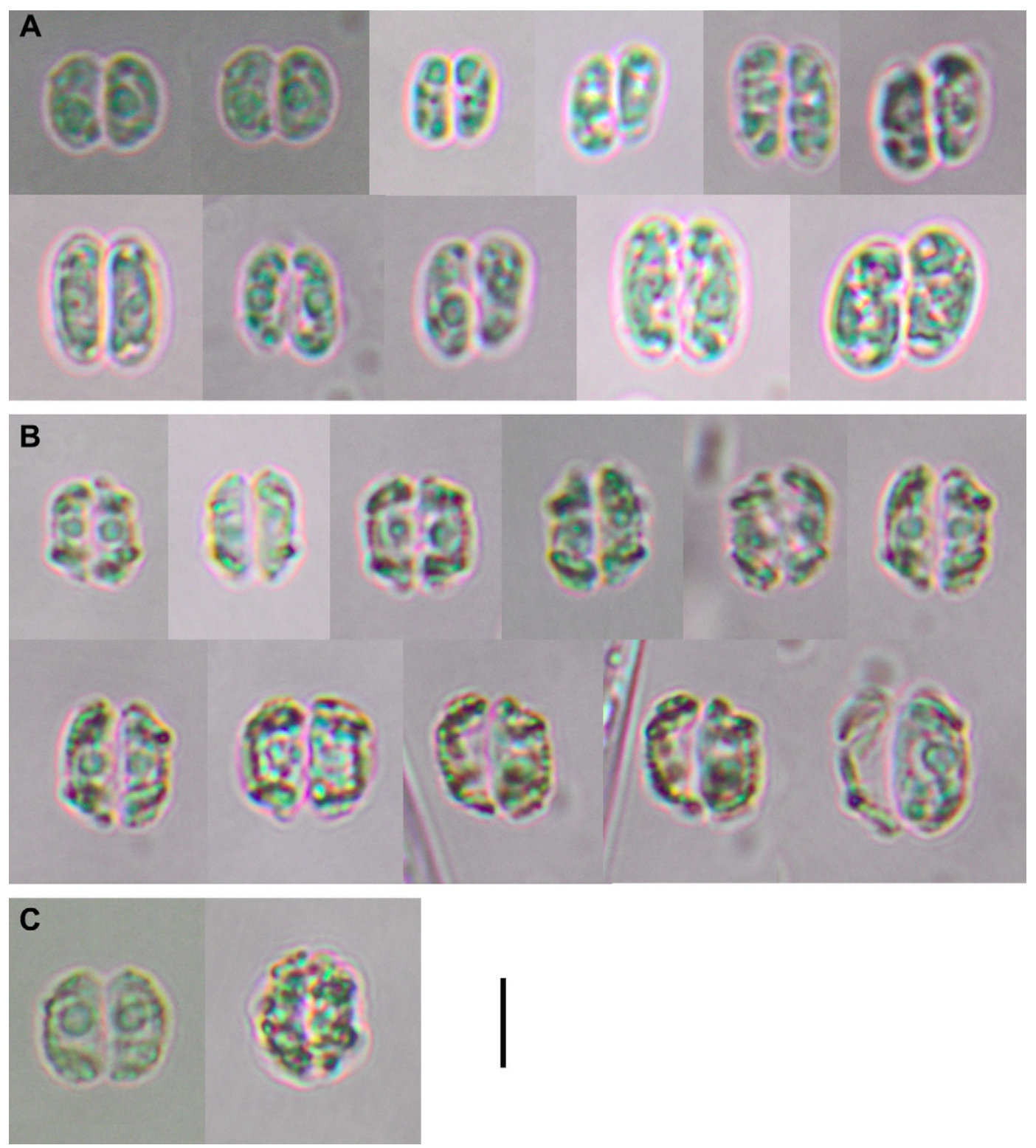

Figure 2. Light microscopic photographs. A. Desmodesmus bicellularis. B. Didymocystis comasii. C. Didymocystis cf. inermis. From samples of the weekly monitoring in the pelagic and coastal zone of Lake Tanganyika near Uvira (D.R. Congo) between September 2011 and October 2013. Scale bar $=5 \mu \mathrm{m}$.

Nov. 2011; CCA 1716; 6 Dec. 2011; CCA 1724; 13 Dec. 2011; CCA 1732; 20 Dec. 2011; CCA 1740; 27 Dec. 2011; CCA 1748; 3 Jan. 2012; CCA 1756; 10 Jan. 2012; CCA 1764; 24 Jan. 2012; CCA 1780; 1 Feb. 2012; 1788; 7 Feb. 2012; CCA 1796; 14 Feb. 2012; CCA 1804; 28 Feb. 2012. CCA 2173; 6 Mar. 2012; CCA 2179; 13 Mar. 2012; CCA 2185; 27 Mar. 2012; CCA 2197; 3 Apr. 2012; CCA 2203; 10 Apr. 2012; CCA 2209; 17 Apr. 2012: CCA 2215; 24 Apr. 2012; CCA 2221; 3 May 2012; CCA 2227; 8 May 2012; CCA 2233; 22 May 2012; CCA 2245; 29 May 2012; CCA 2251; 5 Jun. 2012; CCA 2258; 12 Jun. 2012; CCA 2264; 26 Jun. 2012; CCA 2276; 3 Jul. 2012; CCA 2282; 10 Jul. 2012; CCA 2288; 17 Jul. 2012; CCA 2294; 24 Jul. 2012; CCA 2301; 31 Jul. 2012; CCA 2307; 7 Aug. 2012; CCA 2313; 14 Aug. 2012; CCA 2319; 21 Aug. 2012; CCA 2325; 28 Aug. 2012; CCA 2331; 11 Sept. 2012; CCA 2343; 18 Sept. 2012; CCA 2350; 28 Sept. 2012; CCA 2356; 2 Oct. 2012; CCA 2362; 9 Oct. 2012; CCA 2368; 16 Oct. 2012;
CCA 2374; 24 Oct. 2012; CCA 2380; 30 Oct. 2012; CCA 2386; 6 Nov. 2012; CCA 2392; 13 Nov. 2012; CCA 2398; 20 Nov. 2012; CCA 2404; 4 Dec. 2012; CCA 2416; 11 Dec. 2012; CCA 2422; 18 Dec. 2012; CCA 2429; 24 Dec. 2012; CCA 2435; 2 Jan. 2013; CCA 2441; 8 Jan. 2013; CCA 2447; 15 Jan. 2013; CCA 2453; 22 Jan. 2013; CCA 2459; 29 Jan 2013; CCA 2465; 5 Feb. 2013; CCA 2471; 12 Feb. 2013; CCA 2477; 19 Feb. 2013; CCA 2483; 26 Feb. 2013; CCA 2489; 6 Mar. 2013; CCA 2846; 12 Mar. 2013: CCA 2853; 19 Mar. 2013; CCA 2860; 26 Mar. 2013; CCA 2867; 2 Apr. 2013; CCA 2874; 9 Apr. 2013; CCA 2881; 16 Apr. 2013; CCA 2888; 23 Apr. 2013; CCA 2895; 29 Apr. 2013; CCA 2902; 7 May 2013; CCA 2909; 14 May 2013; CCA 2916; 24 May 2013; CCA 2923; 28 May 2013; CCA 2930; 4 Jun. 2013; CCA 2937; 18 Jun. 2013; CCA 2952; 25 Jun. 2013; CCA 2959; 2 Jul. 2013; CCA 2966; 9 Jul. 2013; CCA 2973; 16 Jul. 2013; CCA 2980; 23 Jul. 2013; CCA 2987; 29 Jul. 2013; CCA 2994; 13 Aug. 2013; 
CCA 3008; 20 Aug. 2013; CCA 3015; 27 Aug. 2013; CCA 3022; 3 Sept. 2013; CCA 3029; 10 Sept. 2013; CCA 3036; 17 Sept. 2013; CCA 3043; 24 Sept. 2013; CCA 3050; 1 Oct. 2013; CCA 3057; 8 Oct. 2013; CCA 3064; 15 Oct. 2013; CCA 3071.

Identification. Coenobia are composed of two cells. Cells are slightly elongated, oval to cylindrical with broadly rounded to slightly conically rounded. Both cells of the coenobium are connected parallel on the ventral side. Cell wall is smooth and a mucilaginous envelop is absent. One parietal chloroplast is present with one pyrenoid which is not clearly visible in young cells. Cell dimensions observed in the Uvira materials, 4.9-8.8 $\times$ 2.4-4.1 $\mu \mathrm{m}$, correspond to those given by Komárek and Fott (1983), 4.5-10 × 2-4 $\mu \mathrm{m}$.

Seasonal fluctuations. At the end of August 2011, the highest number of colonies of $D$. bicellularis was observed in the pelagic surface waters (116 cells per ml) followed by a small peak at the end of June 2012 (80 cells per ml) (Fig. 3). During the rest of the monitoring period the taxon was most of the time present in the phytoplankton counts but in very low number and never reaching 20 cells per $\mathrm{ml}$. In the coastal surface waters maximum densities were observed in September and October 2011 with 158 and 234 cells per $\mathrm{ml}$ and a smaller peak in October 2013 with 86 cells per ml (Fig. 3). During the rest of the monitoring never more than 15 colonies per $\mathrm{ml}$ were observed.

Ecology. According to Komárek and Fott (1983) this taxon lives free in the periphyton, or more rarely in the plankton, scattered to frequent.

Distribution. Common in Central Europe (Komárek and Fott 1983) and also reported from France, the Netherlands, Portugal, Spain, and Scandinavia (Guiry 2020). This taxon was also reported from Brazil (Ferragut et al. 2005; Menezes 2010 in Guiry 2020), and China and Taiwan (Liu and $\mathrm{Hu}$ et al. 2012; Shao 2003-2014 in Guiry 2020) (Fig. 4A). Reported from Lake Tanganyika between Kigoma (Tanzania) and Mpulungu (Zambia) (Vuorio et al. 2003), and near Kigoma as Didymocystis cf. bicellularis by Cocquyt and Vyverman (2005).

Order Chlorellales

Family Oocystaceae

\section{Didymocystis comasii Komárek (1983)}

Figure 2B

New records. D.R. CONGO • Sud-Kivu, Uvira, Lake Tanganyika; $03^{\circ} 25.648^{\prime} \mathrm{S}, 029^{\circ} 07.969^{\prime} \mathrm{E} ; 775 \mathrm{~m}$ a.s.1.; surface water; CHOLTIC expedition members leg.; CCA numbers in BR: 26 Aug. 2011; CCA 1602; 7 Sept. 2011; CCA 1618; 13 Sept. 2011; CCA 1626, 20 Sept. 2011; CCA 1634; 27 Sept. 2011; CCA 1642; 4 Oct. 2011; CCA 1650; 12 Oct. 2011; CCA 1658; 18 Oct. 2011; CCA 1666; 25 Oct. 2011; CCA 1674; 1 Nov. 2011; CCA 1682; 15 Nov. 2011; CCA 1698; 22 Nov. 2011; CCA 1706; 29 Nov. 2011; CCA 1714; 6 Dec. 2011; CCA 1722; 13 Dec. 2011; CCA 1730;
20 Dec. 2011; CCA 1738; 27 Dec. 2011; CCA 1746; 3 Jan. 2012; CCA 1754; 10 Jan. 2012; CCA 1762; 17 Jan. 2012; CCA 1770; 24 Jan. 2012; CCA 1778; 1 Feb. 2012; 1786; 7 Feb. 2012; CCA 1794; 14 Feb. 2012; CCA 1802; 21 Feb. 2012; CCA 2165; 28 Feb. 2018; CCA 2171; 6 Mar. 2012; CCA 2177; 13 Mar. 2012; CCA 2183; 20 Mar. 2012; CCA 2189; 27 Mar. 2012; CCA 2195; 3 Apr. 2012; CCA 2201; 24 Apr. 2012; CCA 2219; 3 May 2012; CCA 2225; 8 May 2012; CCA 2231; 22 May 2012; CCA 2243; 29 May 2012; CCA 2249; 5 Jun. 2012; CCA 2256; 12 Jun. 2012; CCA 2262; 19 Jun. 2012; CCA 2268; 26 Jun. 2012; CCA 2274; 3 Jul. 2012; CCA 2280; 10 Jul. 2012; CCA 2286; 17 Jul. 2012; CCA 2292; 24 Jul. 2012; CCA 2299; 31 Jul. 2012; CCA 2305; 7 Aug. 2012; CCA 2311; 14 Aug. 2012; CCA 2317; 21 Aug. 2012; CCA 2323; 28 Aug. 2012; CCA 2329; 4 Sept.2012; CCA 2335; 11 Sept. 2012; CCA 2341; 18 Sept. 2012; CCA 2348; 28 Sept. 2012; CCA 2354; 2 Oct. 2012; CCA 2360; 9 Oct. 2012; CCA 2366; 16 Oct. 2012; CCA 2372; 24 Oct. 2012; CCA 2378; 30 Oct. 2012; CCA 2384; 6 Nov. 2012; CCA 2390; 13 Nov. 2012; CCA 2396; 20 Nov. 2012; CCA 2402; 27 Nov. 2012; CCA 2408; 4 Dec. 2012; CCA 2414; 11 Dec. 2012; CCA 2420; 18 Dec. 2012; CCA 2427; 24 Dec. 2012; CCA 2433; 2 Jan. 2013; CCA 2439; 8 Jan. 2013; CCA 2445; 15 Jan. 2013; CCA 2451; 22 Jan. 2013; CCA 2457; 29 Jan 2013; CCA 2463; 5 Feb. 2013; CCA 2469; 12 Feb. 2013; CCA 2475; 19 Feb. 2013; CCA 2481; 26 Feb. 2013; CCA 2487; 6 Mar. 2013; CCA 2844; 12 Mar. 2013; CCA 2851; 19 Mar. 2013; CCA 2858; 26 Mar. 2013; CCA 2865; 2 Apr. 2013; CCA 2872; 9 Apr. 2013; CCA 2879; 16 Apr. 2013; CCA 2886; 23 Apr. 2013; CCA 2893; 29 Apr. 2013; CCA 2900; 7 May 2013; CCA 2907; 14 May 2013; CCA 2914; 24 May 2013; CCA 2921; 28 May 2013; CCA 2928; 4 Jun. 2013; CCA 2935; 11 Jun. 2013; CCA 2943; 18 Jun. 2013; CCA 2950; 25 Jun. 2013; CCA 2957; 2 Jul. 2013; CCA 2964; 9 Jul. 2013; CCA 2971; 23 Jul. 2013; CCA 2985; 29 Jul. 2013; CCA 2992; 6 Aug. 2013; CCA 2999; 13 Aug. 2013; CCA 3006; 20 Aug. 2013; CCA 3013; 27 Aug. 2013; CCA 3020; 3 Sept. 2013; CCA 3027; 17 Sept. 2013; CCA 3041; 24 Sept. 2013; CCA 3048; 1 Oct. 2013; CCA 3055; 8 Oct. 2013; CCA 3062; 15 Oct. 2013; CCA 3069 • Sud-Kivu, Uvira, Lake Tanganyika; $03^{\circ} 24.945^{\prime} \mathrm{S}, 029^{\circ} 10.635^{\prime} \mathrm{E} ; 775 \mathrm{~m}$ a.s.1.; surface water; CHOLTIC expedition members leg.; CCA numbers in BR: 26 Aug. 2011; CCA 1604; 7 Sept. 2011; CCA 1620; 13 Sept. 2011; CCA 1628; 20 Sept. 2011; CCA 1636; 27 Sept. 2011; CCA 1644; 4 Oct. 2011; CCA 1652; 12 Oct. 2011; CCA 1660; 18 Oct. 2011; CCA 1668; 25 Oct. 2011; CCA 1676; 1 Nov. 2011; CCA 1684; 15 Nov. 2011; CCA 1700; 22 Nov. 2011; CCA 1708; 29 Nov. 2011; CCA 1716; 6 Dec. 2011; CCA 1724; 13 Dec. 2011; CCA 1732; 20 Dec. 2011; CCA 1740; 27 Dec. 2011; CCA 1748; 10 Jan. 2012; CCA 1764; 17 Jan. 2012; CCA 1772; 24 Jan. 2012; CCA 1780; 1 Feb. 2012; 1788; 7 Feb. 2012; CCA 1796; 14 Feb. 2012; CCA 1804; 21 Feb. 2012; CCA 2167; 28 Feb. 2012; CCA 2173; 6 Mar. 2012; CCA 2179; 13 Mar. 2012; CCA 2185; 20 Mar. 2012; CCA 2191; 27 Mar. 2012; CCA 2197; 3 Apr. 2012; CCA 2203; 10 Apr. 2012; CCA 2209; 17 Apr. 2012: CCA 2215; 24 Apr. 2012; CCA 2221; 

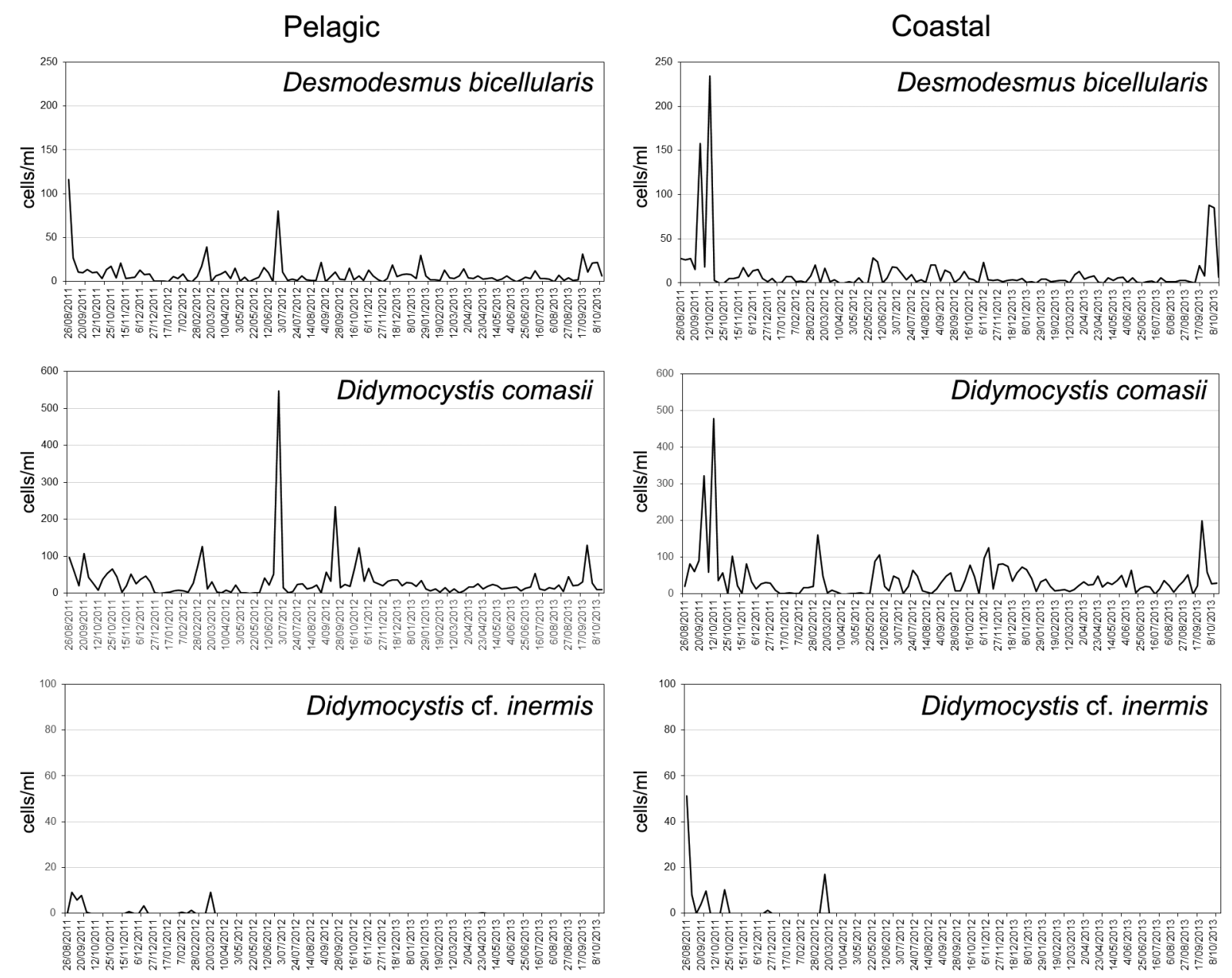

Figure 3. Number of cells of Desmodesmus bicellularis, Didymocystis comasii, and Didymocystis cf. inermis per ml lake water as observed during the weekly monitoring in the pelagic and coastal zone of Lake Tanganyika near Uvira (D.R. Congo) between September 2011 and October 2013.

3 May 2012; CCA 2227; 8 May 2012; CCA 2233; 22 May 2012; CCA 2245; 29 May 2012; CCA 2251; 5 Jun. 2012; CCA 2258; 12 Jun. 2012; CCA 2264; 19 Jun. 2012; CCA 2270; 26 Jun. 2012; CCA 2276; 3 Jul. 2012; CCA 2282; 10 Jul. 2012; CCA 2288; 17 Jul. 2012; CCA 2294; 24 Jul. 2012; CCA 2301; 31 Jul. 2012; CCA 2307; 7 Aug. 2012; CCA 2313; 14 Aug. 2012; CCA 2319; 21 Aug. 2012; CCA 2325; 28 Aug. 2012; CCA 2331; 4 Sept. 2012; CCA 2337; 11 Sept. 2012; CCA 2343; 18 Sept. 2012; CCA 2350; 28 Sept. 2012; CCA 2356; 2 Oct. 2012; CCA 2362; 9 Oct. 2012; CCA 2368; 16 Oct. 2012; CCA 2374; 24 Oct. 2012; CCA 2380; 30 Oct. 2012; CCA 2386; 6 Nov. 2012; CCA 2392; 13 Nov. 2012; CCA 2398; 20 Nov. 2012; CCA 2404; 27 Nov. 2012; CCA 2410; 4 Dec. 2012; CCA 2416; 11 Dec. 2012; CCA 2422; 18 Dec. 2012; CCA 2429; 24 Dec. 2012; CCA 2435; 2 Jan. 2013; CCA 2441; 8 Jan. 2013; CCA 2447; 15 Jan. 2013; CCA 2453; 22 Jan. 2013; CCA 2459; 29 Jan 2013; CCA 2465; 5 Feb. 2013; CCA 2471; 12 Feb. 2013; CCA 2477; 19 Feb. 2013; CCA 2483; 26 Feb. 2013; CCA 2489; 6 Mar. 2013; CCA 2846; 12 Mar. 2013: CCA 2853; 19 Mar. 2013; CCA 2860; 26 Mar. 2013; CCA 2867; 2 Apr. 2013; CCA 2874; 9 Apr. 2013; CCA 2881; 16 Apr. 2013; CCA 2888; 23 Apr. 2013; CCA 2895; 29 Apr. 2013; CCA 2902; 7 May 2013; CCA 2909; 14 May 2013; CCA
2916; 24 May 2013; CCA 2923; 28 May 2013; CCA 2930; 4 Jun. 2013; CCA 2937; 11 Jun. 2013; CCA 2945; 18 Jun. 2013; CCA 2952; 25 Jun. 2013; CCA 2959; 2 Jul. 2013; CCA 2966; 9 Jul. 2013; CCA 2973; 16 Jul. 2013; CCA 2980; 23 Jul. 2013; CCA 2987; 29 Jul. 2013; CCA 2994; 6 Aug. 2013; CCA 3001; 13 Aug. 2013; CCA 3008; 20 Aug. 2013; CCA 3015; 27 Aug. 2013; CCA 3022; 3 Sept. 2013; CCA 3029; 10 Sept. 2013; CCA 3036; 17 Sept. 2013; CCA 3043; 24 Sept. 2013; CCA 3050; 1 Oct. 2013; CCA 3057; 8 Oct. 2013; CCA 3064; 15 Oct. 2013; CCA 3071.

Identification. Coenobia are composed of two cells. Cells are more or less spindle-like and shortly conical at the ends. Both cells of the coenobium are connected parallel on the ventral side. Cell wall is smooth except for an irregular granulation forming a transapical ridge near both cell ends. Sometimes both ridges are connected by a longitudinal ridge on the dorsal side of the cells. Brownish incrustations are often present giving the coenobia a typical color. One parietal chloroplast is present. A pyrenoid was not observed, but according to Komárek (1983) a pyrenoid must be present although often indistinct or invisible. Cell dimensions observed in the Uvira materials, $6.0-10.0 \times 2.3-4.4 \mu \mathrm{m}$, are somewhat larger than those given by Komárek and Fott (1983), 6-9.2 × 1.2-2.5 

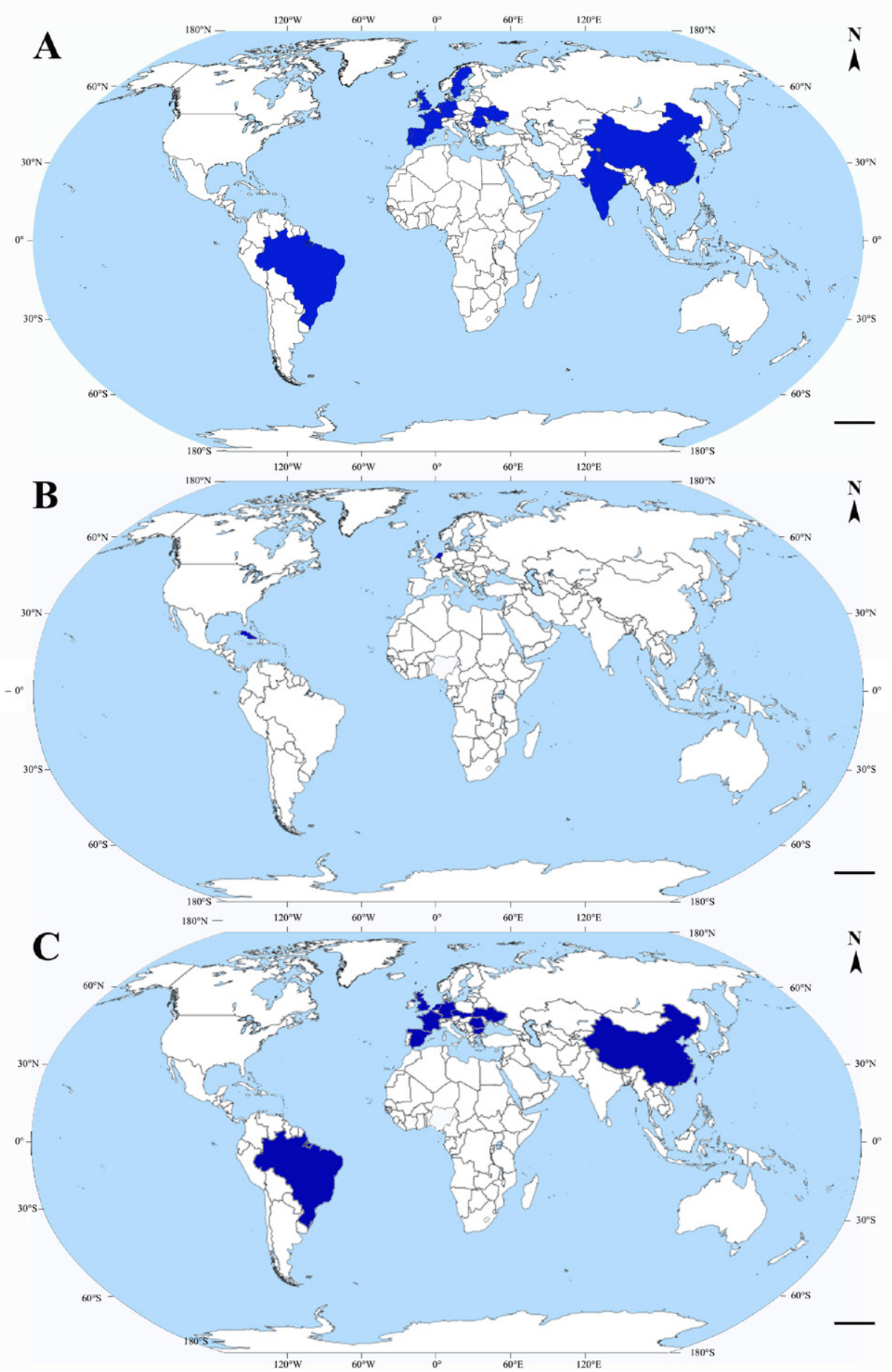

Figure 4. Geographical distribution of (A) Desmodesmus bicellularis, (B) Didymocystis comasii, and (C) Didymocystis inermis, represented by the countries from which the taxa were reported from as given in the literature data, with exception of the reports from Lake Tanganyika. (Map source: Wikimedia Commons, modified). Scale bar $=2000 \mathrm{~km}$ (equatorial scale).

$\mu \mathrm{m}$.

Seasonal fluctuations. In the pelagic surface waters this taxon reached it maximum with more than 500 cells per $\mathrm{ml}$ at the end of June 2012, while a smaller peak was observed in September 2012 with around 220 cells per ml (Fig. 3). At four other occasions (September 2011, March 2012, October 2012 and September 2013) this taxon attained more than 100 cells per $\mathrm{ml}$. In the coastal surface waters maximum densities of this taxon were observed in September and October 2011, with 320 and 470 cells per $\mathrm{ml}$ respectively, and in September 2013 with 200 cells per ml (Fig. 3). At three other occasions (November 2011, June 2012 and November 2012) this taxon attained more than 100 cells per ml. Didymocystis comasii was observed in most of the weekly taken phytoplankton samples of the pelagic and coastal surface waters, with a tendence of larger numbers of colonies in the coastal waters compared to the pelagic.

Ecology. Komárek \& Fott (1983) reported this taxon from detritus and free floating between aquatic plants of small, slightly eutrophic watertanks where it was rare. 
Distribution. According to Komárek and Fott (1983) this species was only reported from Cuba, but more recently this taxon was also reported from the Netherlands (Veen et al. 2015 in Guiry 2020) (Fig. 4B). Reported from Lake Tanganyika near Kigoma (Tanzania) as Didymocystis cf. comasii by Cocquyt \& Vyverman (2005).

Didymocystis cf. inermis (Fott) Fott in Komárek (1973) Figure 2C

Basionym: Dicellula inermis Fott

New records. D.R. CONGO • Sud-Kivu, Uvira, Lake Tanganyika; $03^{\circ} 25.648^{\prime} \mathrm{S}, 029^{\circ} 07.969^{\prime} \mathrm{E}$; $775 \mathrm{~m}$ a.s.l.; surface water; CHOLTIC expedition members leg.; CCA numbers in BR: 26 Aug. 2011; CCA 1602; 7 Sept. 2011; CCA 1618; 20 Sept. 2011; CCA 1634; 27 Sept. 2011; CCA 1642; 25 Oct. 2011; CCA 1674; 20 Dec. 2011; CCA 1738; 13 Mar. 2012; CCA 2183; and $03^{\circ} 24.945^{\prime} \mathrm{S}, 029^{\circ} 10.635^{\prime} \mathrm{E}$; 775 m a.s.l.; surface water; CHOLTIC expedition members leg.; CCA numbers in BR: 7 Sept. 2011; CCA 1620; 13 Sept. 2011; CCA 1628; 20 Sept. 2011; CCA 1636; 27 Sept. 2011; CCA 1644; 22 Nov. 2011; CCA 1708; 13 Dec. 2011; CCA 1732; 7 Feb. 2012; CCA 1796; 21 Feb. 2012; CCA 2167; 20 Mar. 2012; CCA 2191; 23 Apr. 2013; CCA 2985.

Identification. Coenobia are composed of two cells. An indistinctly delimited mucilageous layer which is often surrounding the coenobium (Komárek and Fott 1983) was not observed. Cell wall rough and ornamented with irregularly distributed warts. One parietal chloroplast present without pyrenoid. Cells dimensions observed in the Uvira materials, $6.4-7.9 \times 2.6-4.0 \mu \mathrm{m}$.

The observed cells differ from the description given by Komárek and Fott (1983) in the smaller dimensions of the cells $(6.4-7.9 \times 2.6-4.0 \mu \mathrm{m}$ versus $8-13 \times 3-6 \mu \mathrm{m})$, and the coarser and less distinct irregularly distributed warts on the cell wall.

Seasonal fluctuations. This taxon was only sporadically observed during the phytoplankton analyses of the surface waters of Lake Tanganyika. In the pelagic zone this taxon was present in September, November and December 2011, February and March 2012, and April 2013 but always with less than 10 colonies per $\mathrm{ml}$ (Fig. 3). In the coastal samples up to 50 cells per ml were observed in August 2011, but during the rest of the monitoring (September, October and December 2011, and March 2012) never more than 20 cells per ml (Fig. 3).

Ecology. In the plankton of eutrophic water (Komárek and Fott 1983).

Distribution. A distribution map of D. inermis (GBIF Secretariat 2019) shows the presence of this taxon in the Netherlands, Germany, and Estonia. However, Komárek and Fott (1983) are convinced that this taxon is probably more widely distributed in the temperate regions in Europe. Besides Europe, this species is also reported from Brazil (Bicudo et al. 1999 in Guiry 2020) and China and Taiwan (Liu and Hu et al. 2012; Shao 2003-2014 in Guiry 2020) (Fig. 4C). Didymocystis cf. comasii was reported by Cocquyt and Vyverman (2005) from Lake Tanganyika near Kigoma (Tanzania).

\section{Discussion}

In 1994, Hegewald et al. (1994) put Didymocystis inermis, together with its var. minima Tell and D. polonica Bucka, in synonymy with Scenedesmus costato-granulati Skuja. However, a couple of years later, new research based on ITS-2 ribosomal DNA data revealed that $D$. inermis belongs not to Scenedesmus but indeed to an independent genus (An et al. 1999). The cells of the taxon observed in Lake Tanganyika have smaller dimensions and often a smaller number of warts on the cell wall than $D$. inermis. This may fall within the variability of $D$. inermis or indicate that the cells belong to another unknown species. We hope that in the future this can be demonstrated through molecular analyses. However, such analyses are not possible on the Lake Tanganyika material taken during the weekly sampling between September 2011 and October 2013 due to the preservation of the samples in formalin.

Up to now, the three taxa discussed here have not yet been reported for the African continent in published databases (Guiry in Guiry and Guiry 2020) (Table 1). In 2005, Cocquyt and Vyverman mentioned the presence of three Didymocystis taxa in the pelagic waters of Lake Tanganyika near Kigoma, Tanzania (04 ${ }^{\circ} 51.26^{\prime} \mathrm{S}$, $\left.029^{\circ} 35.54^{\prime} \mathrm{E}\right)$. These observations were done during a biweekly phytoplankton monitoring of the lake from February 2002 to February 2004. However, the identification in samples taken near Kigoma to species was uncertain and were therefore referred to as "cf." (conferatum) (Cocquyt and Vyverman 2005). Although the same microscopic analysis method (Utermöhl 1958) was used, the 2002-2004 counts were made at a magnification of 400 times and not at 1000 times as in this study. The taxa referred to as Didymocystis cf. bicellularis (Chod.) Kom., Didymocystis cf. comasii Kom., and Didymocystis cf. inermes (Fott) Fott, are the same three taxa as were observed in Lake Tanganyika, near Uvira (D.R. Congo). Better observations in the materials from Uvira allowed for the identity of two taxa, Didymocystis cf. bicellularis and Didymocystis cf. comasii, to be confirmed as Desmodesmus bicellularis and Didymocystis comasii, respectively.

The hypothesis that Desmodesmus bicellularis is more common in coastal areas of Lake Tanganyika, as suggested by Cocquyt and Vyverman (2005), could not be confirmed. This hypothesis was put forward to explain why the "Didymocystis" taxa were not observed in an earlier phytoplankton studied in 1975 (Hecky et al. 1978) but reported from a phytoplankton study of pelagic samples taken in 1998 between Kigoma (Tanzania) and Mpulungu (Zambia) (Vuorio et al. 2003).

In general, the highest number of colonies of the three discussed taxa was observed around the end of the dry season (August-September). In the annual limnological 
Table 1. Overview of the Didymocystis and Pseudodidymocystis taxa and their distribution as given by Guiry in Guiry and Guiry (2020), n.i. if not indicated. In bold taxa that are accepted taxonomically (Guiry in Guiry and Guiry 2020); taxa with an asterisk have not been subjected to any kind of verification (Guiry in Guiry and Guiry 2020).

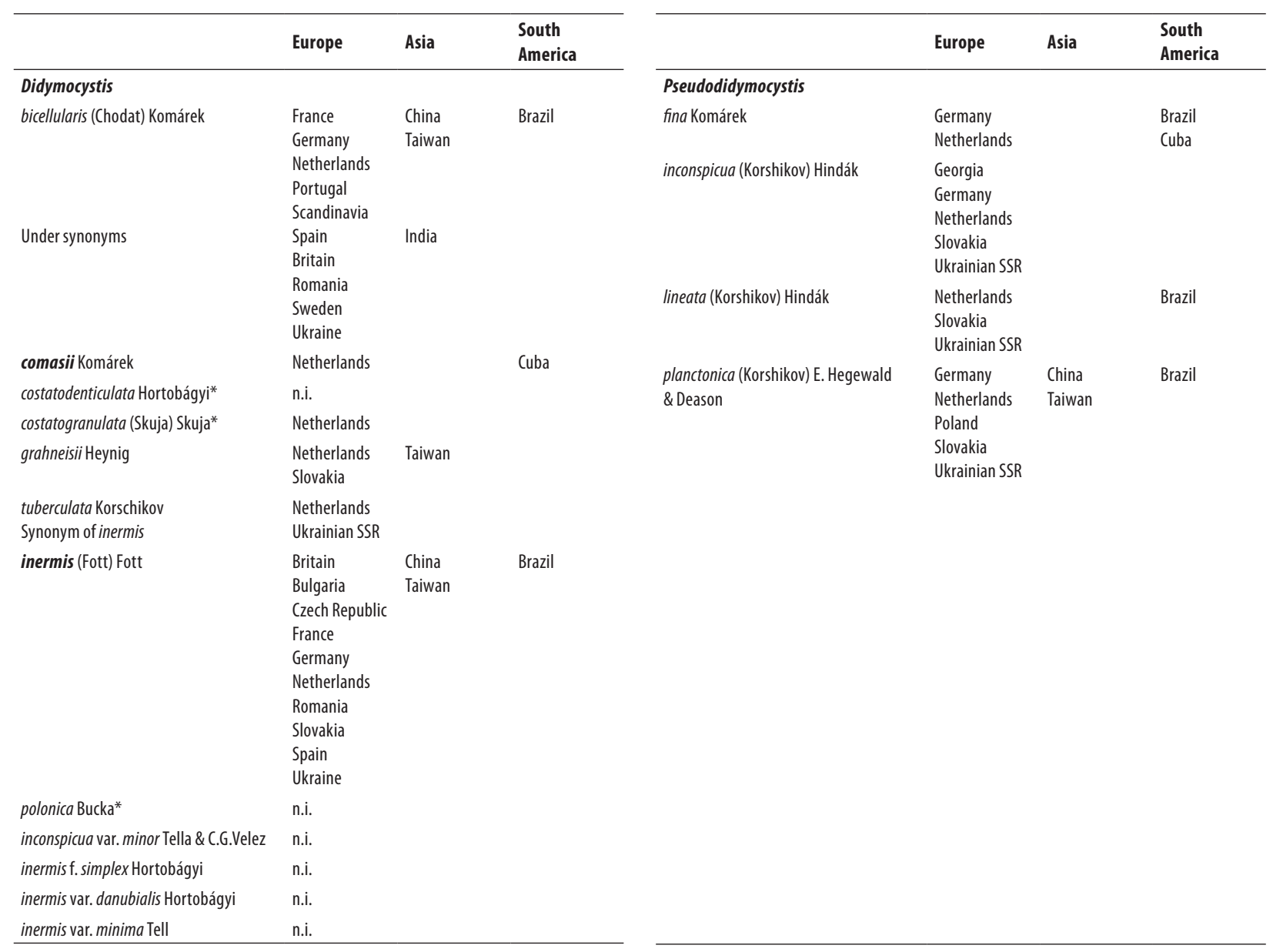

cycle of Lake Tanganyika, this is a period of secondary upwellings when nutrient-rich deep-water layers are raised towards the surface following the end of southern trade winds inducing oscillations of water layers (detailed information on the limnological cycle of Lake Tanganyika can be found in Plisnier et al. 1999).

\section{Acknowledgements}

The CHOLTIC (Cholera outbreaks at Lake Tanganyika induced by Climate Change?) project was funded by the Belgian Science Policy (Research Program Science for a Sustainable Development, project number SD/AR/04A). The authors are very grateful to the local team of the "Centre de Recherche en Hydrobiologie" at Uvira (D.R. Congo) for running the weekly sampling.

\section{Authors' Contributions}

$\mathrm{CC}$ wrote and edited the manuscript and did most of the phytoplankton analyses. LC helped with the phytoplankton counts. NM was responsible from the sampling in Lake Tanganyika. PDP analysed the limnological data and critically read the manuscript.

\section{References}

An SS, Friedl T, Hegewald E (1999) Phylogenetic relationships of Scenedesmus and Scenedesmus-like coccoid green algae as inferred from ITS-2 rDNA sequence comparisons. Plant Biology 1 (4): $418-428$.

Chodat R (1926) Scenedesmus. Étude de génétique, de systématique expérimentale et d'hydrobiologie. Schweizerische Zeitschrift für Hydrologie 3: 71-258.

Cocquyt C, Vyverman W (2005) Phytoplankton in Lake Tanganyika: a comparison of community composition and biomass off Kigoma with previous studies 27 years ago. Journal of Great Lakes Research 31 (4): 535-546. https://doi.org/10.1016/S0380-1330(05)70 282-3

Cocquyt C, Vyverman W, Compère P (1993) A checklist of the algal flora of the East African Great Lakes: Lake Malawi, Lake Tanganyika and Lake Victoria. Scripta Botanica Belgica 8: 1-56.

Colwell RR (1996) Global climate and infectious disease: the cholera paradigm. Science 274 (5295): 2025-2031. https://doi.org/10.1126/ science.274.5295.2025

Descy J-P, Plisnier P-D, Leporcq B, Sténuite S, Pirlot S, Stimart J, Gosselain V, André L, Alleman L, Langlet D, Vyverman W, Cocquyt C, De Wever A, Stoyneva MP, Deleersnijder E, Naithani J, Chitamwebwa D, Chande A, Kimirei I, Sekadende B, Mwaitega S, Muhoza S, Sinyenza D, Makasa L, Lukwessa C, Zulu I, Phiri H (2005) CLIMLAKE, Climate variability as recorded in Lake Tanganyika. Final Report. Belgian Science Policy, Brussels, 119 pp.

GEOCAT geocat.kew.org. Accessed on: 2020-12-12.

GBIF Secretariat (2019) Desmodesmus bicellularis (Chodat) S.S.An, 
Friedl \& E.Hegewald. In: GBIF backbone taxonomy. Checklist dataset. https://doi.org/10.15468/39omei. Accessed on: 2020-1023.

Guiry MD, Guiry GM (2020) AlgaeBase. National University of Ireland, Galway, Ireland. http://www.algaebase.org. Accessed on: 2020-08-20.

Hecky RE, Fee EJ, Kling H, Rudd JWM (1978) Studies in the planktonic ecology of Lake Tanganyika. Technical Report 816. Department of Fisheries and Environment, Fisheries and Marine Service, Western Region, Winnipeg, Canada, 51 pp.

Hegewald E, Krienitz L, Schnepf E (1994) Studies on Scenedesmus costato-granulatus Skuja. Nova Hedwigia 56 (1-2): 97-127.

Hegewald E, Deason TR (1989) Pseudodidymocystis, a new genus of Scenedesmaceae (Chlorophyceae). Algological Studies 55: 119127.

Hillebrand H, Dürselen C-D, Kirschtel D, Pollingher U, Zohary T (1999) Biovolume calculation for pelagic and benthic microalgae. Journal of Phycology 35: 403-424. https://doi.org/10.1046/j.15298817.1999.3520403.x

Hindák F (1990) Studies on the chlorococcal algae (Chlorophyceae). V. Biologické Práce 36: 1-227.

Komárek J (1973) Taxonomische Begrenzung der Gattung Didymocystis Kors. (Scenedesmaceae, Chlorococcales). Preslia 45: 311-314.

Komárek J (1983) Contribution to the chlorococcal algae of Cuba. Nova Hedwigia 37: 65-180.
Komárek J, Fott B (1983) Chlorophyceae, Ordnung Chlorococcales. In: Huber-Pestalozzi G (Ed.) Die Binnengewässer, Band XVI. Das Phytoplankton des Süsswassers Systematik und Biologie. 7. Teil, 1. Hälfte. E. Schweizerbart'Sche Verlagbuchhandlung, Stuttgart, Germany, 1044 pp.

Plisnier P-D, Chitamwebwa D, Mwape L, Tshibangu K, Langenberg V, Coenen E (1999) Limnological annual cycle inferred from physical-chemical fluctuations at three stations of Lake Tanganyika. Hydrobiologia 407: 45-58.

Plisnier P-D, Poncelet N, Cocquyt C, De Boeck H, Bompangue D, Naithani J, Jacobs J, Piarroux R, Moore S, Giraudoux P, Batumbo D, Mushagalusa D, Makasa L, Deleersnijder E, Tomazic I, Cornet Y (2015). Cholera outbreaks at Lake Tanganyika induced by climate change? - "CHOLTIC". Final report. Belgian Science Policy, Brussels, Belgium, $117 \mathrm{pp}$.

Utermöhl H (1958) Zur Vervollkommnung der quantitative Phytoplankton-Methodik. Mitteilungen der Internationalen Vereinigung für theoretische und angewandte Limnologie 9: 1-38.

Vuorio K, Nuottajärvi M, Sarvala K, Sarvala,J (2003) Spatial distribution of phytoplankton and picocyanobacteria in Lake Tanganyika in March and April 1998. Aquatic Ecosystem Health and Management 6: 263-278. https://doi.org/10.1080/146340390236135

Wikimedia commons (2020) https://commons.wikimedia.org/wiki/ File:World_Map_Blank___with_blue_sea.svg. Accessed on: 202012-09.

\section{Appendix}

Table A1. Collection dates and numbers of the phytoplankton samples, taken during the weekly monitoring from the surface waters in the pelagic and coastal zone near Uvira, D.R. Congo, in which Desmodesmus bicellularis, Didymocystis comasii, and Didymocystis cf. inermis have been observed.

\begin{tabular}{|c|c|c|c|c|c|c|c|c|}
\hline \multicolumn{3}{|c|}{ Date } & \multicolumn{3}{|c|}{ Collection number pelagic site } & \multicolumn{3}{|c|}{ Collection number coastal site } \\
\hline Year & Month & Day & D. bicellularis & D. comasii & D. cf. inermis & D. bicellularis & D. comasii & D. cf. inermis \\
\hline 2011 & 8 & 26 & CCA 1604 & CCA 1604 & - & CCA 1602 & CCA 1602 & CCA 1602 \\
\hline 2011 & 9 & 7 & CCA 1620 & CCA 1620 & CCA 1620 & CCA 1618 & CCA 1618 & CCA 1618 \\
\hline 2011 & 9 & 13 & CCA 1628 & CCA 1628 & CСA 1628 & CCA 1626 & CCA 1626 & - \\
\hline 2011 & 9 & 20 & CCA 1636 & CCA 1636 & CCA 1636 & CCA 1634 & CCA 1634 & CCA 1634 \\
\hline 2011 & 9 & 27 & CCA 1644 & CCA 1644 & CCA 1644 & CCA 1642 & CCA 1642 & CCA 1642 \\
\hline 2011 & 10 & 4 & CCA 1652 & CCA 1652 & - & CCA 1650 & CCA 1650 & - \\
\hline 2011 & 10 & 12 & CCA 1660 & CCA 1660 & - & CCA 1658 & CCA 1658 & - \\
\hline 2011 & 10 & 18 & CCA 1668 & CCA 1668 & - & CCA 1666 & CCA 1666 & - \\
\hline 2011 & 10 & 25 & CCA 1676 & CCA 1676 & - & - & CCA 1674 & CCA 1674 \\
\hline 2011 & 11 & 1 & CCA 1684 & CCA 1684 & & CCA 1682 & CCA 1682 & - \\
\hline 2011 & 11 & 15 & CCA 1700 & CCA 1700 & - & CCA 1698 & CCA 1698 & - \\
\hline 2011 & 11 & 22 & CCA 1708 & CCA 1708 & CCA 1708 & CCA 1706 & CCA 1706 & - \\
\hline 2011 & 11 & 29 & CCA 1716 & CCA 1716 & - & CCA 1714 & CСA 1714 & - \\
\hline 2011 & 12 & 6 & ССА 1724 & CCA 1724 & - & CCA 1722 & CCA 1722 & - \\
\hline 2011 & 12 & 13 & CCA 1732 & CCA 1732 & CCA 1732 & CCA 1730 & CCA 1730 & - \\
\hline 2011 & 12 & 20 & CCA 1740 & CCA 1740 & - & CCA 1738 & CCA 1738 & CCA 1738 \\
\hline 2011 & 12 & 27 & CСA 1748 & CCA 1748 & - & CCA 1746 & CCA 1746 & - \\
\hline 2012 & 1 & 3 & CCA 1756 & - & - & CCA 1754 & CCA 1754 & - \\
\hline 2012 & 1 & 10 & CCA 1764 & CCA 1764 & - & - & CCA 1762 & - \\
\hline 2012 & 1 & 17 & - & CCA 1772 & - & CCA 1770 & ССА 1770 & - \\
\hline 2012 & 1 & 24 & CCA 1780 & CCA 1780 & - & CCA 1778 & CCA 1778 & - \\
\hline 2012 & 2 & 1 & CCA 1788 & CCA 1788 & - & CCA 1786 & CCA 1786 & - \\
\hline 2012 & 2 & 7 & CCA 1796 & CCA 1796 & CCA 1796 & CCA 1794 & CCA 1794 & - \\
\hline 2012 & 2 & 14 & CCA 1804 & CCA 1804 & - & CCA 1802 & CCA 1802 & - \\
\hline 2012 & 2 & 21 & - & CCA 2167 & CCA 2167 & CCA 2165 & CCA 2165 & - \\
\hline-2012 & 2 & 28 & CCA 2173 & CCA 2173 & - & CCA 2171 & CCA 2171 & - \\
\hline 2012 & 3 & 6 & CCA 2179 & CCA 2179 & - & CCA 2177 & CCA 2177 & - \\
\hline 2012 & 3 & 13 & CCA 2185 & CCA 2185 & - & - & CCA 2183 & CCA 2183 \\
\hline 2012 & 3 & 20 & - & CCA 2191 & CCA 2191 & CCA 2189 & CCA 2189 & - \\
\hline 2012 & 3 & 27 & CCA 2197 & CCA 2197 & - & CCA 2195 & CCA 2195 & - \\
\hline 2012 & 4 & 3 & CCA 2203 & CCA 2203 & - & CCA 2201 & CCA 2201 & - \\
\hline 2012 & 4 & 10 & CCA 2209 & CCA 2209 & - & - & - & - \\
\hline
\end{tabular}




\begin{tabular}{|c|c|c|c|c|c|c|c|c|}
\hline \multicolumn{3}{|c|}{ Date } & \multicolumn{3}{|c|}{ Collection number pelagic site } & \multicolumn{3}{|c|}{ Collection number coastal site } \\
\hline Year & Month & Day & D. bicellularis & D. comasii & D. cf. inermis & D. bicellularis & D. comasii & D. cf. inermis \\
\hline 2012 & 4 & 17 & CCA 2215 & CCA 2215 & - & - & - & - \\
\hline 2012 & 4 & 24 & CCA 2221 & CCA 2221 & - & CCA 2219 & CCA 2219 & - \\
\hline 2012 & 5 & 3 & CCA 2227 & CCA 2227 & - & CCA 2225 & CCA 2225 & - \\
\hline 2012 & 5 & 8 & CCA 2233 & CCA 2233 & - & CCA 2231 & CCA 2231 & - \\
\hline 2012 & 5 & 22 & CCA 2245 & CCA 2245 & - & - & CCA 2243 & - \\
\hline 2012 & 5 & 29 & CCA 2251 & CCA 2251 & - & ССА 2249 & CCA 2249 & - \\
\hline 2012 & 6 & 5 & CCA 2258 & CCA 2258 & - & CCA 2256 & CCA 2256 & - \\
\hline 2012 & 6 & 12 & CCA 2264 & CCA 2264 & - & - & CCA 2262 & - \\
\hline 2012 & 6 & 19 & - & CCA 2270 & - & CCA 2268 & CCA 2268 & - \\
\hline 2012 & 6 & 26 & CCA 2276 & CCA 2276 & - & CCA 2274 & CCA 2274 & - \\
\hline 2012 & 7 & 3 & CCA 2282 & CCA 2282 & - & CCA 2280 & CCA 2280 & - \\
\hline 2012 & 7 & 10 & CCA 2288 & CCA 2288 & - & CCA2286 & CCA 2286 & - \\
\hline 2012 & 7 & 17 & CCA 2294 & CCA 2294 & - & CCA 2292 & CCA 2292 & - \\
\hline 2012 & 7 & 24 & CCA 2301 & CCA 2301 & - & CCA 2299 & CCA 2299 & - \\
\hline 2012 & 7 & 31 & CCA 2307 & CCA 2307 & - & CCA2305 & CCA 2305 & - \\
\hline 2012 & 8 & 7 & CCA 2313 & CCA 2313 & - & CCA 2311 & CCA 2311 & - \\
\hline 2012 & 8 & 14 & CCA 2319 & CCA 2319 & - & CCA 2317 & CCA 2317 & - \\
\hline 2012 & 8 & 21 & CCA 2325 & CCA 2325 & - & CCA 2323 & CCA 2323 & - \\
\hline 2012 & 8 & 28 & CCA 2331 & CCA 2331 & - & CCA 2329 & CCA 2329 & - \\
\hline 2012 & 9 & 4 & - & CCA 2337 & - & CCA 2335 & CCA 2335 & - \\
\hline 2012 & 9 & 11 & CCA 2343 & CCA 2343 & - & CCA 2341 & CCA 2341 & - \\
\hline 2012 & 9 & 18 & CCA 2350 & CCA 2350 & - & CCA 2348 & CCA 2348 & \\
\hline 2012 & 9 & 28 & CCA 2356 & CCA 2356 & - & CCA 2354 & CCA 2354 & - \\
\hline 2012 & 10 & 2 & CCA 2362 & CCA 2362 & - & CCA 2360 & CCA 2360 & - \\
\hline 2012 & 10 & 9 & CCA 2368 & CCA 2368 & - & CCA 2366 & CCA 2366 & - \\
\hline 2012 & 10 & 16 & CCA 2374 & CCA 2374 & - & CCA 2372 & CCA 2372 & - \\
\hline 2012 & 10 & 24 & CCA 2380 & CCA 2380 & - & CCA 2378 & CCA 2378 & - \\
\hline 2012 & 10 & 30 & CCA 2386 & CCA 2386 & - & CCA 2384 & CCA 2384 & - \\
\hline 2012 & 11 & 6 & CCA 2392 & CCA 2392 & - & CCA 2390 & CCA 2390 & - \\
\hline 2012 & 11 & 13 & CCA 2398 & ССА 2398 & - & CCA2396 & ССА 2396 & - \\
\hline 2012 & 11 & 20 & CCA 2404 & CCA 2404 & - & CCA 2402 & CCA 2402 & - \\
\hline 2012 & 11 & 27 & - & CCA 2410 & - & CCA 2408 & CCA 2408 & - \\
\hline 2012 & 12 & 4 & CCA 2416 & CCA 2416 & - & CCA 2414 & CCA 2414 & - \\
\hline 2012 & 12 & 11 & CCA 2422 & CCA 2422 & - & CCA 2420 & CCA 2420 & - \\
\hline 2012 & 12 & 18 & CCA 2429 & CCA 2429 & - & CCA 2427 & CCA 2427 & - \\
\hline 2012 & 12 & 24 & CCA 2435 & CCA 2435 & - & CCA 2433 & CCA 2433 & - \\
\hline 2013 & 1 & 2 & CCA 2441 & CCA 2441 & - & CCA 2439 & CCA 2439 & - \\
\hline 2013 & 1 & 8 & CCA 2447 & CCA 2447 & - & CCA 2445 & CCA 2445 & - \\
\hline 2013 & 1 & 15 & CCA 2453 & CCA 2453 & - & CCA 2451 & CCA 2451 & - \\
\hline 2013 & 1 & 22 & CCA 2459 & CCA 2459 & - & - & CCA 2457 & - \\
\hline 2013 & 1 & 29 & CCA 2465 & CCA 2465 & - & CCA 2463 & CCA 2463 & - \\
\hline 1013 & 2 & 5 & CCA 2471 & CCA 2471 & - & CCA 2469 & CCA 2469 & - \\
\hline 2013 & 2 & 12 & CCA 2477 & CCA 2477 & - & CCA 2475 & CCA 2475 & - \\
\hline 2013 & 2 & 19 & CCA 2483 & CCA 2483 & - & CCA 2481 & CCA 2481 & - \\
\hline 2013 & 2 & 26 & CCA 2489 & CCA 2489 & - & CCA 2487 & CCA 2487 & - \\
\hline 2013 & 3 & 6 & CCA 2846 & CCA 2846 & - & CCA 2844 & CCA 2844 & \\
\hline 2013 & 3 & 12 & CCA 2853 & CCA 2853 & - & - & CCA 2851 & - \\
\hline 2013 & 3 & 19 & CCA 2860 & CCA 2860 & - & CCA 2858 & CCA 2858 & - \\
\hline 2013 & 3 & 26 & CCA 2867 & CCA 2867 & - & CCA 2865 & CCA 2865 & - \\
\hline 2013 & 4 & 2 & CCA 2874 & CCA 2874 & - & CCA 2872 & CCA 2872 & - \\
\hline 2013 & 4 & 9 & CCA 2881 & CCA 2881 & - & CCA 2879 & CCA 2879 & - \\
\hline 2013 & 4 & 16 & CCA 2888 & CCA 2888 & - & CCA 2886 & CCA 2886 & - \\
\hline 2013 & 4 & 23 & CCA 2895 & CCA 2895 & CCA 2895 & ССА 2893 & CCA 2893 & - \\
\hline 2013 & 4 & 29 & CCA 2902 & CCA 2902 & - & - & CCA 2900 & - \\
\hline 2013 & 5 & 7 & CCA 2909 & CCA 2909 & - & CCA 2907 & CCA 2907 & - \\
\hline 2013 & 5 & 14 & CCA 2916 & CCA 2916 & - & CCA 2914 & CCA 2914 & - \\
\hline 2013 & 5 & 24 & CCA 2923 & CCA 2923 & - & CCA 2921 & CCA 2921 & - \\
\hline 2013 & 5 & 28 & CCA 2930 & CCA 2930 & - & CCA 2928 & CCA 2928 & - \\
\hline 2013 & 6 & 4 & CCA 2937 & CCA 2937 & - & CCA 2935 & CCA 2935 & - \\
\hline 2013 & 6 & 11 & - & CCA 2945 & - & CCA 2943 & CCA 2943 & - \\
\hline
\end{tabular}




\begin{tabular}{|c|c|c|c|c|c|c|c|c|}
\hline \multicolumn{3}{|c|}{ Date } & \multicolumn{3}{|c|}{ Collection number pelagic site } & \multicolumn{3}{|c|}{ Collection number coastal site } \\
\hline Year & Month & Day & D. bicellularis & D. comasii & D. cf. inermis & D. bicellularis & D. comasii & D. cf. inermis \\
\hline 2013 & 6 & 18 & CCA 2952 & CCA 2952 & - & CCA 2950 & CCA 2950 & - \\
\hline 2013 & 6 & 25 & CCA 2959 & CCA 2959 & - & - & CCA 2957 & - \\
\hline 2013 & 7 & 2 & CCA 2966 & CCA 2966 & - & CCA 2964 & CCA 2964 & - \\
\hline 2013 & 7 & 9 & CCA 2973 & CCA 2973 & - & CCA 2971 & CCA 2971 & - \\
\hline 2013 & 7 & 16 & CCA 2980 & CCA 2980 & - & - & - & - \\
\hline 2013 & 7 & 23 & CCA 2987 & CCA 2987 & - & CCA 2985 & CCA 2985 & - \\
\hline 2013 & 7 & 29 & CCA 2994 & CCA 2994 & - & CCA 2992 & CCA 2992 & - \\
\hline 2013 & 8 & 6 & - & CCA 3001 & - & CCA 2999 & CCA 2999 & - \\
\hline 2013 & 8 & 13 & CCA 3008 & CCA 3008 & - & CCA 3006 & CCA 3006 & - \\
\hline 2013 & 8 & 20 & CCA 3015 & CCA 3015 & - & CCA 3013 & CCA 3013 & - \\
\hline 2013 & 8 & 27 & CCA 3022 & CCA 3022 & - & CCA 3020 & CCA 3020 & - \\
\hline 2013 & 9 & 3 & CCA 3029 & CCA 3029 & - & CCA 3027 & CCA 3027 & - \\
\hline 2013 & 9 & 10 & CCA 3036 & CCA 3036 & - & - & - & - \\
\hline 2013 & 9 & 17 & CCA 3043 & CCA 3043 & - & CCA 3041 & CCA 3041 & - \\
\hline 2013 & 9 & 24 & CCA 3050 & CCA 3050 & - & CCA 3048 & CCA 3048 & - \\
\hline 2013 & 10 & 1 & CCA 3057 & CCA 3057 & - & CCA 3055 & CCA 3055 & - \\
\hline 2013 & 10 & 8 & CCA 3064 & CCA 3064 & - & CCA 3062 & CCA 3062 & - \\
\hline 2013 & 10 & 15 & CCA 3071 & CCA 3071 & - & CCA 3069 & CCA 3069 & - \\
\hline
\end{tabular}

